\title{
OPTIMIZATION PARAMETERS FOR SEED GERMINATION AND MICROPROPAGATION OF TIGER ORCHID, GRAMMATOPHYLLUM SPECIOSUM
}

\author{
${ }^{1}$ Zuraida Ab Rahman, ${ }^{1}$ Ayu Nazreena Othman, \\ ${ }^{2}$ Amirah Balqis Amir Amran and ${ }^{1}$ Nur Najwa Arifah Basiron \\ ${ }^{1}$ Biotechnology \& Nanotechnology Research Centre, Malaysian Agricultural Research and Development Institute, \\ MARDI HQ, Persiaran MARDI-UPM, 43400 Serdang Selangor, Malaysia. \\ ${ }^{2}$ School of Agriculture Science \& Biotechnology, Faculty of Bioresources and Food Industry, Universiti Sultan \\ Zainal Abidin, Besut Campus, 22200, Besut, Terengganu, Malaysia \\ *Corresponding Author \\ DOI: https://doi.org/10.51193/IJAER.2021.7401
}

\begin{abstract}
Micropropagation is one of the ways to conserve a species and the aim of this study is to optimize the seed germination and also micropropagation of tiger orchid (Grammatophyllum speciosum).The first part is to optimize the seed germination of tiger orchid where full-strength MS media supplemented with $30 \%$ sucrose with the addition of $5 \mathrm{mg} / \mathrm{L}$ of BAP is the most preferable condition to germinate the seeds of tiger orchids where the germination recorded at 95 $\%$ followed by full strength B5 which the germination recorded at $80 \%$. The optimization for micropropagation for Grammatophyllum speciosum is identified in this study where the medium supplemented with $0.2 \%$ charcoal and $1 \mathrm{mg} / \mathrm{L}$ of BAP produce the heaviest PLB (13.5 g) while the medium supplemented with $1 \mathrm{mg} / \mathrm{L}$ of BAP with no presence of charcoal contributed to the highest number of shoots (95).
\end{abstract}

Keywords: Grammatophyllum speciosum, tiger orchid, PLB, BAP

\section{INTRODUCTION}

The world's largest orchid with the scientific name Grammatophyllum speciosum from the family of Orchidaceae is commonly known as the Tiger Orchid. Tiger orchids have striking flower patterns in the colour of yellow with brown spots resembling a tiger, hence, the name. 
This ornamental plant is largely distributed in tropical rainforests stretching from Malaysia, Thailand, the Philippines, and Indonesia (Sahakitpichan et al., 2013).

Diversification of usage of the tiger orchid ranged from human consumption and even up to medicinal uses. In Malaysia, the locals of the Kelabit community in Sarawak made tiger orchids as one of the local delicacies whereas, in the Iban community, tiger orchid is used as a traditional remedy to treat wounds and also jaundice (Chee, 2015). Other than that, different parts of tiger orchids can be used as treatments for skin rashes, fever, and also anemia (Chowjarean et al., 2019).

The propagation of tiger orchids is usually done by pseudobulb cutting (Montria et al., 2009) where pseudobulbs are pod-like shape structures and grow under the leaves of the orchids. However, conventional propagations are tedious and hence this is where micropropagation is useful to obtain a large number of plants in small spaces considering nowadays land scarcity is a major problem. Morphologically, tiger orchids have bisexual flowers indicating that a flower consists of both male and female sexual organs which are crucial in reproduction. However, as reported by Pitoyo et al., (1970), tiger orchids are difficult to self-pollinate and the urgent need for pollinators is vital. Other than that, Pitoyo et al., (1970) also reported that tiger orchids that are successfully fertilized have difficulties in germinating because of the lacked endosperm that acts as food reservation as well as undeveloped embryos. Thus, optimization of micropropagation of tiger orchids is very much needed to utilize the plants at their maximum capacity.

\section{MATERIALS AND METHODS}

\section{Plant materials}

The pods of Grammatophyllum speciosum orchid were collected from cultivated plants and were surface sterilized using 50\% ethanol which was followed by dipping into $15 \%$ (v/v) sodium hypochlorite $(\mathrm{NaOCl})$ solution containing $0.5 \%(\mathrm{v} / \mathrm{v})$ Tween-20 for $10 \mathrm{~min}$, rinsed three times with sterile distilled water. Then, the pods were cut vertically over a sterile Petri-dish. The seeds were then removed and placed in a treatment medium (Figure 1a).

\section{Seed germination and plant regeneration}

The seeds of Grammatophyllum speciosum were cultured on treatment media; half-strength Murashige and Skoog (MS), full-strength MS, half-strength Knudson C, full-strength Knudson C, half strength Woody Plant Medium (WPM), full-strength WPM, half strength B5, and also full strength B5. Other than that, the medium was also supplemented with various concentrations of sucrose $(20 \%, 30 \%$, and $40 \%)$ alongside either $1 \mathrm{mg} / \mathrm{L} \mathrm{BAP}$ or $5 \mathrm{mg} / \mathrm{L}$ BAP. 
International Journal of Agriculture and Environmental Research

ISSN: 2455-6939

Volume: 07, Issue: 04 "July-August 2021"

All the cultures were maintained in a culture room supplemented with fluorescent light with a light intensity of 3000 lux and a photoperiodic period of 16 hours at $25 \pm 2{ }^{\circ} \mathrm{C}$. The duration for seed germination of Grammatophyllum speciosum took 6 months of culture. The germination rate of the seeds was observed and recorded.

After seed germination, the treatment that produced highest germination rate was used for the next part of the experiment which is the plant regeneration. The obtained cultures (seeds-derived protocorms) (Figure 1e) that were chosen have a $95 \%$ germination rate and were cultured on MS media with $5 \mathrm{mg} / \mathrm{L}$ of BAP as seen in Table 1.For the micropropagation and regeneration treatment, the seeds-derived protocorms were cultured for on medium supplemented with $0,0.1$, 0.2 or $0.3 \%$ of charcoal, either $1 \mathrm{mg} / \mathrm{L}$ or $5 \mathrm{mg} / \mathrm{L}$ of BAP and with a constant percentage of sucrose $(30 \%)$. Several parameters were recorded and the parameters include the PLBs weight $(\mathrm{g})$, number of shoots, and also the length of shoots $(\mathrm{cm})$. The data were collected two months after the protocorms grew. All cultures were maintained under $25 \pm 2{ }^{\circ} \mathrm{C}$ under 16 hours photoperiod with a light intensity of 3000 lux.

\section{Acclimatization}

Shoots that are $4-5 \mathrm{~cm}$ in length were removed from the cultured flasks and rinsed under running tap water. Individual plantlets were then transferred into pot containing a 1:1 ratio of topsoil and also organic soil. Plants that were transplanted were kept under a glasshouse (75\% shading) with regular watering.

\section{RESULTS AND DISCUSSION}

In this study, the percentage of seed germination of Grammatophyllum speciosum induced by a different type of medium (half-strength Murashige and Skoog (MS), full-strength MS, half strength Knudson C, full-strength Knudson C, half strength Woody Plant Medium (WPM), fullstrength WPM, half strength B5 and also full strength B5) can be seen in Table 1. Other than that, it can also be seen in Table 1, the seed germination differed according to the percentage of sucrose and also the concentration of BAP which is either $1 \mathrm{mg} / \mathrm{L}$ or $5 \mathrm{mg} / \mathrm{L}$.

For $1 \mathrm{mg} / \mathrm{L}$ of BAP, the percentage varied from $20 \%$ to $60 \%$ based on the percentage of sucrose present. However, with the same percentage of sucrose, there is a significant difference wherein $5 \mathrm{mg} / \mathrm{L}$ of BAP, the highest seed germination $(95 \%)$ can be seen when the pods are cultured in $30 \%$ sucrose in full strength MS media. In comparison, in $1 \mathrm{mg} / \mathrm{L}$ of BAP, pods with $30 \%$ sucrose in MS media only have $60 \%$ seed germination (Figure 1b-d). The percentage gap is tremendous and hence this suggested that $5 \mathrm{mg} / \mathrm{L}$ of BAP in MS media is suitable for seed germination of Grammatophyllum speciosum. Similar findings can be seen in Pimseen\& Kanchanapoom, (2011). In a study conducted by Sopalun et al., (2010), where half-strength MS 
International Journal of Agriculture and Environmental Research

ISSN: 2455-6939

Volume: 07, Issue: 04 "July-August 2021"

media have the highest seed germination of Grammatophyllum speciosum compared to other media used, but in a study by Samala et al., (2014) showed that half strength of MS media only resulted in $76.5 \%$ of seed germination of tiger orchid and the study did not conduct seed germination of full-strength MS media. Other than that, Nontachaiyapoom et al., (2011) reported that seed germination of tiger orchid in symbiotic with fungi in MS media is higher than in Oat Meal Agar (OMA) although OMA is frequently used for culturing fungi, MS media still reflected higher seed germination of tiger orchid. Nevertheless, this still further proves that MS media is suitable for seed germination of tiger orchids.

As for the concentration of BAP, Ageng Rineksane et al., (2018) stated that BAP increases the multiplication of tiger orchids while another study by Markal et al., (2015)also stated that BAP heightens the germination of Grammatophyllum speciosum but with the concentration of $1 \mathrm{mg} / \mathrm{L}$. However, the study by Markal et al., (2015) used either $0.5 \mathrm{mg} / \mathrm{L}$ or $1.0 \mathrm{mg} / \mathrm{L}$ of BAP which slightly differ from this study that used $1.0 \mathrm{mg} / \mathrm{L}$ and $5.0 \mathrm{mg} / \mathrm{L}$ of BAP, and this study strengthen the increase of concentration of BAP resulted in better seed germination of tiger orchid. Nevertheless, the essence of the increasing of BAP resulted in better seed germination is also captured in the study by Markal et al., (2015) where $1.0 \mathrm{mg} / \mathrm{L}$ of BAP is preferable in inducing germination compared to $0.5 \mathrm{mg} / \mathrm{L}$ of BAP. Other than that, BAP is also seen to intensify the seed germination of orchid but instead of BAP alone, in a study by Gaurav \& Bijaya,(2016), the combination of $1 \mathrm{mg} / \mathrm{L}$ of BAP and $1 \mathrm{mg} / \mathrm{L}$ of NAA is suitable for seed germination of orchids. Nonetheless, the usage of BAP is crucial in providing better seed germination for orchids.

Table 1: Effect of BAP, sucrose concentration, and type of medium on the germination rate of tiger orchid.

\begin{tabular}{|c|c|c|c|c|c|c|}
\hline \multicolumn{7}{|c|}{ The germination rate of seed culture (\%) } \\
\hline & \multicolumn{3}{|c|}{$1 \mathrm{mg} / \mathrm{L} \mathrm{BAP}$} & \multicolumn{3}{|c|}{$5 \mathrm{mg} / \mathrm{L} \mathrm{BAP}$} \\
\hline Sucrose $(\%)$ & 20 & 30 & 40 & 20 & 30 & 40 \\
\hline $\mathrm{MS}$ & $50 \pm 5.6$ & $60 \pm 12.1$ & $60 \pm 8.1$ & $70 \pm 6.9$ & $95 \pm 5.1$ & $80 \pm 4.5$ \\
\hline $\mathrm{MS}^{1} / 2$ & $40 \pm 2.3$ & $50 \pm 9.8$ & $60 \pm 4.8$ & $70 \pm 5.1$ & $60 \pm 4.4$ & $50 \pm 11.5$ \\
\hline Knudson C & $40 \pm 1.5$ & $50 \pm 11.0$ & $50 \pm 9.7$ & $60 \pm 5.5$ & $40 \pm 12.6$ & $30 \pm 6.5$ \\
\hline Knudson C $1 / 2$ & $35 \pm 5.1$ & $40 \pm 4.5$ & $45 \pm 4.7$ & $70 \pm 6.8$ & $30 \pm 3.1$ & $30 \pm 4.8$ \\
\hline WPM & $35 \pm 8.3$ & $40 \pm 6.8$ & $40 \pm 8.5$ & $50 \pm 11.2$ & $70 \pm 7.5$ & $30 \pm 4.1$ \\
\hline $\mathrm{WPM}^{1} 1 / 2$ & $20 \pm 1.3$ & $30 \pm 8.2$ & $35 \pm 8.0$ & $40 \pm 4.3$ & $60 \pm 13.1$ & $25 \pm 7.9$ \\
\hline B5 & $50 \pm 7.8$ & $30 \pm 4.3$ & $35 \pm 3.5$ & $30 \pm 8.4$ & $80 \pm 15.2$ & $30 \pm 6.3$ \\
\hline $\mathrm{B} 51 / 2$ & $40 \pm 3.4$ & $25 \pm 5.1$ & $20 \pm 3.9$ & $30 \pm 4.6$ & $70 \pm 3.4$ & $30 \pm 2.6$ \\
\hline
\end{tabular}


International Journal of Agriculture and Environmental Research

ISSN: 2455-6939

Volume: 07, Issue: 04 "July-August 2021"

On the other hand, as for Table 2, lower concentrations of BAP $(1 \mathrm{mg} / \mathrm{L})$ are preferable in producing heavier Protocorm Like Bodies (PLB's) which are essential in the micropropagation of tiger orchids (Figure 1f). The heaviest PLB's recorded in this study are both in the media supplemented with $1 \mathrm{mg} / \mathrm{L}$ of BAP with $13.5 \mathrm{~g}(0.2 \%$ charcoal $)$ and $12.3 \mathrm{~g}(0.3 \%$ charcoal $)$ respectively. Generally, from what can be seen in Table 2, the highest number of shoots can be observed in $0 \%$ charcoal supplemented with $1 \mathrm{mg} / \mathrm{L}$ of BAP (Figure $1 \mathrm{~g}$ ). The reason for this might be due to the fact that charcoals are used to induce rooting and other than that is to prevent browning. However, $0 \%$ charcoal in $1 \mathrm{mg} / \mathrm{L}$ BAP demonstrated the lowest weight of PLB's (3.1 g) despite having the highest shoots (95). Other than that, the lowest number of shoots recorded in $1 \mathrm{mg} / \mathrm{L}$ of BAP (41) provided the heaviest PLB's which weight at $13.5 \mathrm{~g}$. The obtained plantlets were transplanted to pots filled with medium. They were maintained at about $70 \%$ relative humidity in the greenhouse with $75 \%$ shading. A survival rate $95 \%$ was achieved after 2 months.

Similar findings can be seen in Susanto et al., (2016) where $1 \mathrm{mg} / \mathrm{L}$ of BAP produce the best response towards the number of shoots (2.20 per explant), however, the study used the combination of BAP with $60 \%$ coconut water instead of charcoal that was used in this study. Other than that, Ageng Rineksane et al., (2018) also reported that $1 \mathrm{mg} / \mathrm{L} \mathrm{BAP}$ with the combination of $75 \%$ rice water is preferable to induce multiplication of Grammatophyllum speciosum. Nevertheless, this further proves that $1 \mathrm{mg} / \mathrm{L}$ of BAP is the optimal concentration for producing Grammatophyllum speciosum shoots.

As for PLB's induction, this study showed that medium with $0.2 \%$ charcoal supplemented with 1 $\mathrm{mg} / \mathrm{L}$ BAP resulted in the heaviest PLB's (13.5 g), and similar findings can be seen through a study conducted by Samala et al., (2014) in which the highest PLB's formation which recorded at $63 \%$ are on half-strength MS media supplemented with the combination of $1.0 \mathrm{mg} / \mathrm{L}$ of BAP and $0.5 \mathrm{mg} / \mathrm{L}$ of NAA, $15 \%$ coconut water and most importantly similar to this study conducted Samala et al., (2014) also used $0.2 \%$ charcoal. Therefore, this further strengthens that the optimal concentration for PLB's induction of tiger orchid is medium supplemented with $0.2 \%$ charcoal supplemented and $1.0 \mathrm{mg} / \mathrm{L}$ BAP. PLB's are essential in the micropropagation of orchids and according to Wattanapan et al., (2018), the medium that has the highest number of PLB's (1.46 per explant) are mediums that have inoculated with charcoal compared to PLB's that have been induced in a medium containing ascorbic acid. Not only that but somaclonal variation is also lessened with the usage of charcoal and TDZ which is preferable to maintain stable genetic lines for PLB's (Chin et al., 2019) which signifies the importance of having charcoal in the medium for PLB induction. 
International Journal of Agriculture and Environmental Research

ISSN: 2455-6939

Volume: 07, Issue: 04 "July-August 2021"

Table 2: Effect charcoal and sucrose concentration of PLBs weight, number of shoots initiated, shoot length after two months that cultured on MS medium supplemented with 1 $\mathrm{mg} / \mathrm{L} \mathrm{BAP}$ or $5 \mathrm{mg} / \mathrm{L}$ BAP.

\begin{tabular}{cccccccc}
\hline $\begin{array}{c}\text { Charcoal } \\
(\%)\end{array}$ & $\begin{array}{c}\text { Sucrose } \\
(\%)\end{array}$ & $\begin{array}{c}\text { PLBs } \\
\text { Weight(g) }\end{array}$ & $\begin{array}{c}\text { Number of } \\
\text { shoots (\#) }\end{array}$ & $\begin{array}{c}\text { shoot } \\
\text { Length } \\
(\mathrm{cm})\end{array}$ & $\begin{array}{c}\text { PLBs } \\
\text { Weight }\end{array}$ & $\begin{array}{c}\text { Number } \\
\text { of shoots }\end{array}$ & $\begin{array}{c}\text { shoot } \\
\text { Length } \\
(\mathrm{cm})\end{array}$ \\
\hline & & & $1 \mathrm{mg} / \mathrm{L} \mathrm{BAP}$ & & & $5 \mathrm{mg} / \mathrm{L}$ BAP \\
\hline 0 & 30 & $3.1 \pm 0.5$ & $95 \pm 10$ & $3-5$ & $6.1 \pm 2.1$ & $44 \pm 6$ & $1-1.5$ \\
& 40 & $2.4 \pm 0.5$ & $54 \pm 11$ & $3-4$ & $5.3 \pm 0.9$ & $34 \pm 6$ & $1-1.5$ \\
\hline 0.1 & 30 & $11.2 \pm 2.1$ & $67 \pm 8$ & $1-3$ & $8.9 \pm 0.7$ & $31 \pm 5$ & $0.5-1$ \\
& 40 & $9.8 \pm 2.1$ & $43 \pm 4$ & $1-2$ & $8.1 \pm 2.2$ & $36 \pm 8$ & $0.5-1$ \\
\hline 0.2 & 30 & $13.5 \pm 1.5$ & $41 \pm 6$ & $1-2$ & $10 \pm 1.5$ & - & - \\
& 40 & $7.7 \pm 2.3$ & $48 \pm 5$ & $1-2$ & $9.0 \pm 1.8$ & - & - \\
\hline 0.3 & 30 & $12.3 \pm 1.0$ & $45 \pm 5$ & $0.5-1.5$ & $6.7 \pm 2.3$ & - & - \\
& 40 & $7.9 \pm 0.6$ & $40 \pm 3$ & $0.5-2.0$ & $7.2 \pm 1.7$ & - & - \\
\hline
\end{tabular}

\section{CONCLUSION}

In conclusion, there have been two objectives achieved in this study whereby the optimization of seed germination of Grammatophyllum speciosum has been identified in which MS media supplemented with $5 \mathrm{mg} / \mathrm{L}$ of BAP are seen to be the optimal condition for the surge of seed germination of Grammatophyllum speciosum. Other than that, the optimization of PLB induction of tiger orchid was also achieved where MS media supplemented with 0.2 charcoal and $1 \mathrm{mg} / \mathrm{L}$ of BAP produce the heaviest PLB. Micropropagation of Grammatophyllum speciosum is crucial to unleashing the full potential of this species and is one of the ways to conserve the species. 


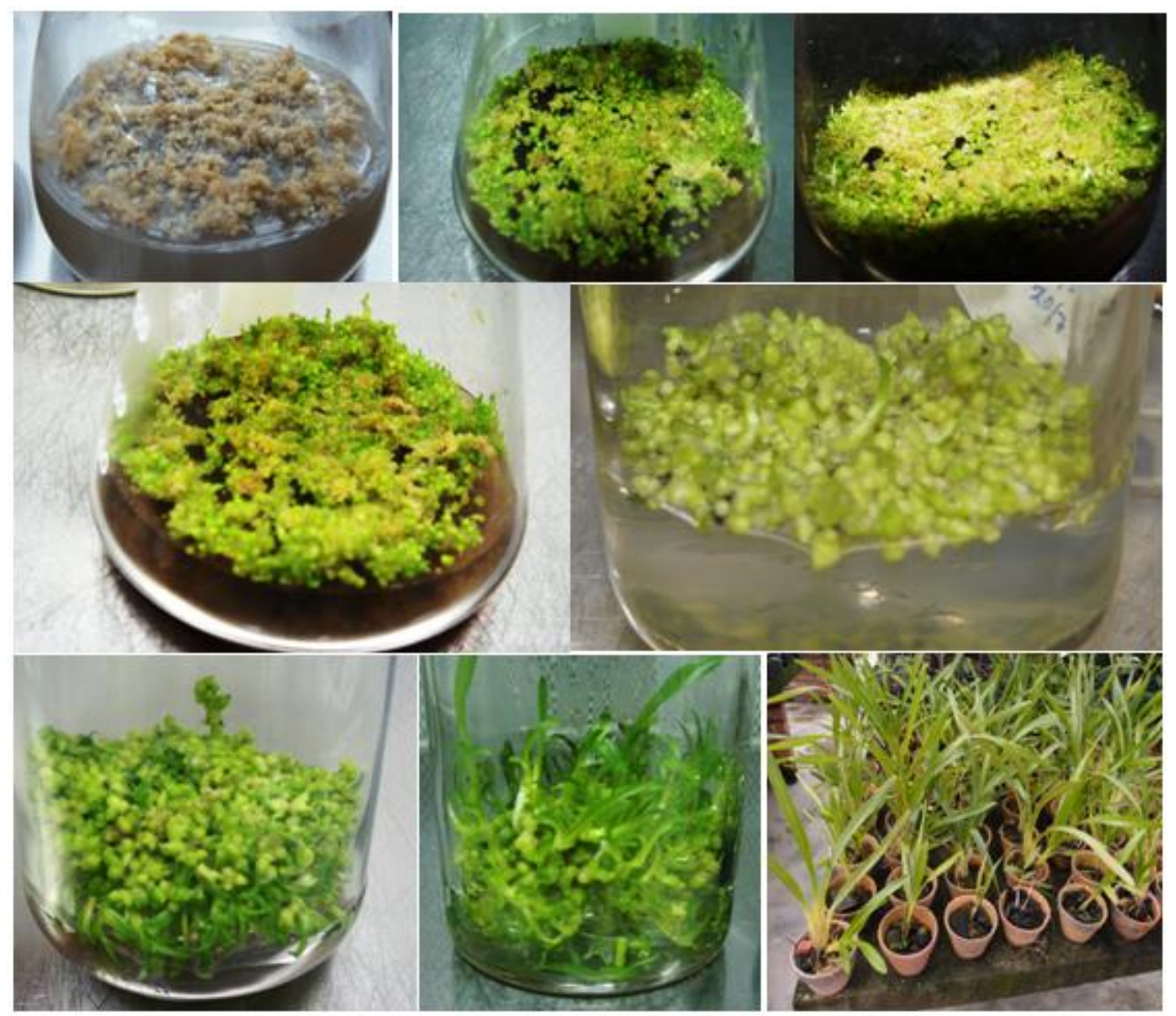

Figure 1: Germination and micropropagation of tiger orchid. (a) Tiger orchid seeds, (b-d) seed germination, (e) Seeds-derived rotocorms after 6 months cultured on germination medium, (f) Protocorm Like Bodies (PLB's), (g) shoot regeneration and (h) 3 months old plants kept at the glasshouse under $75 \%$ shading.

\section{REFERENCES}

Ageng Rineksane, I., Safitri Nafiah, S., \& Susilo Dewi, S. (2018). The Combination of Rice Water and BAP Enhances the Multiplication of Grammatophyllum speciosum. Planta Tropika: Journal of Agro Science, 6(2), 92-99. https://doi.org/10.18196/pt.2018.085.9299

Chee, B. (2015). Know Thy Herb : The Tiger Orchid. July. 
International Journal of Agriculture and Environmental Research

ISSN: 2455-6939

Volume: 07, Issue: 04 "July-August 2021"

Chin, C. K., Lee, Z. H., Mubbarakh, S. A., James Antony, J. J., Chew, B. L., \& Subramaniam, S. (2019). Effects of plant growth regulators and activated charcoal on somaclonal variations of protocorm-like bodies (PLBs) of Dendrobium Sabin Blue orchid. Biocatalysis and Agricultural Biotechnology, 22, 101426. https://doi.org/10.1016/j.bcab.2019.101426

Chowjarean, V., Phiboonchaiyanan, P. P., Harikarnpakdee, S., \& Tengamnuay, P. (2019). A natural skin anti-ageing serum containing pseudobulb ethanolic extract of Grammatophyllum speciosum: a randomized double-blind, placebo-controlled trial. International Journal of Cosmetic Science, 41(6), 548-557. https://doi.org/10.1111/ics.12571

Gaurav, P., \& Bijaya, P. (2016). In vitro seed germination and seedling development of the orchid Coelogyne stricta (D. Don) Schltr. African Journal of Biotechnology, 15(5), 105109. https://doi.org/10.5897/ajb2015.14870

Markal, A., Mayta, N. I., \& Fatonah, S. (2015). PERBANYAKAN ANGGREK Grammatophyllum scriptum (Lindl.) BL. MELALUI INDUKSI TUNAS SECARA IN VITRO DENGAN PENAMBAHAN BAP dan NAA. 2(1), 108-114.

Montria, N., Niumthong, W., \& Janpatiw, A. (2009). Tissue culture of Grammatophyllum speciosum blume, the world largest orchid. Acta Horticulturae, 812, 205-210. https://doi.org/10.17660/actahortic.2009.812.25

Nontachaiyapoom, S., Sasirat, S., \& Manoch, L. (2011). Symbiotic seed germination of Grammatophyllum speciosum Blume and Dendrobium draconis Rchb. f., native orchids of Thailand. Scientia Horticulturae, 130(1), 303-308. https://doi.org/10.1016/j.scienta.2011.06.040

PIMSEN, M., \& KANCHANAPOOM, K. (2011). Effect of Basal Media and Sugar Types on in Vitro Regeneration of Grammatophyllum speciosum Blume. Notulae Scientia Biologicae, 3(3), 101-104. https://doi.org/10.15835/nsb336153

PITOYO, A., HANI, M. R., \& ANGGARWULAN, E. (1970). Application of chitosan spraying on acclimatization success of tiger orchid (Grammatophyllum scriptum) plantlets. Nusantara Bioscience, 7(2), 185-191. https://doi.org/10.13057/nusbiosci/n070222

Sahakitpichan, P., Mahidol, C., Disadee, W., Chimnoi, N., Ruchirawat, S., \& Kanchanapoom, T. (2013). Glucopyranosyloxybenzyl derivatives of (R)-2-benzylmalic acid and (R)-eucomic 
acid, and an aromatic glucoside from the pseudobulbs of Grammatophyllum speciosum. Tetrahedron, 69(3), 1031-1037. https://doi.org/10.1016/j.tet.2012.11.082

Samala, S., Te-Chato, S., Yenchon, S., \& Thammasiri, K. (2014). Protocorm-like body proliferation of Grammatophyllum speciosum through asymbiotic seed germination. ScienceAsia, 40(6), 379-383. https://doi.org/10.2306/scienceasia1513-1874.2014.40.379

Sopalun, K., Thammasiri, K., \& Ishikawa, K. (2010). Micropropagation of the Thai orchid Grammatophyllum speciosum blume. Plant Cell, Tissue and Organ Culture, 101(2), 143-150. https://doi.org/10.1007/s11240-010-9671-2

Susanto, D., Isda, M. N., \& Fatonah, S. (2016). PERBANYAKAN ANGGREK MACAN (Grammatophyllum scriptum (L.) Blume) SECARA IN VITRO DARI EKSPLAN TUNAS PADA MEDIA VACIN AND WENT. 1-9.

Wattanapan, N., Srichuay, W., Klinnawee, L., \& Meesawat, U. (2018). รองเท้านารีม่วงสงขลา: Paphiopedilum callosum var . sublaeve Effects of anti-browning agents on protocormlike body induction using thin cell layers of Endangered Lady's Slipper Orchid: Paphiopedilum callosum var. sublaeve. 107-116. 